\title{
MERAWAT KEBERAGAMAN MENJAGA TOLERANSI MENEROPONG PERAN FORUM KERUKUNAN UMAT BERAGAMA KABUPATEN SIKKA
}

\author{
M. Harudin ${ }^{1)}$, Khaidir ${ }^{2)}$, H. Rodja Abdul Natsir ${ }^{3)}$ \\ 1, 2,3 Program Studi Pendidikan Pancasila dan Kewarganegaraan \\ Fakultas Pendidikan Ilmu Sosial dan Humaniora \\ IKIP Muhamammadiyah Maumere \\ 1Email:mharudinpkn@gmail.com \\ 2Email:khaidiraslam1970@gmail.com \\ 3Email: natsirodja15@gmail.com
}

\begin{abstract}
ABSTRAK
Pemerintah mempunyai tugas dan kewajiban melindungi setiap warga negara untuk memeluk agama masing-masing serta memberikan bimbingan pengajaran yang dapat dilaksanakan dengan aman dan tertib, berdasarkan undang-undang yang berlaku. Penelitian ini bertujuan untuk mengetahui peran forum kerukunan umat beragama dalam menjaga toleransi antar umat beragama di Kabupaten Sikka. Penelitian ini menggunakan pendekatan kualitatif. Pengumpulan data menggunakan teknik pengamatan, wawancara, dan studi dokumentasi. Informan dalam wawancara adalah tokoh agama. Hasil penelitian yang diperoleh yaitu: FKUB sudah melakukan berbagai kegiatan sesuai tupoksi anatara lain sebagai mediator dan motivator, FKUB melakukan sosialisasi, nilai-nilai dalam masing-masing agama, melakukan dialog dengan pemuka agama dan tokoh masyarakat, menampung dan menyalurkan aspirasi ormas keagamaan serta aspirasi masyarakat namun terkendala pada faktor biaya operasional.
\end{abstract}

Kata kunci: Keberagaman, Toleransi dan Peran FKUB

\section{ABSTRACT}

The government has the duty and obligation to protect every citizen from embracing their respective religions and providing teaching guidance that can be carried out safely and in an orderly manner, based on applicable laws. This study aims to determine the role of religious harmony forums in maintaining tolerance between religious communities in the Sikka Regency. This research uses a qualitative approach data collection using observation techniques, interviews, and study documentation. The informants in the interview are religious leaders. The results obtained are: FKUB has carried out various activities following the duties and functions of other mediators and motivators, FKUB conducted socialization, values in each religion, held dialogues with religious leaders and community leaders, accommodated and channeled the aspirations of religious organizations and goals society but is constrained by operational cost factors.

Keywords: Diversity, Tolerance, Role of FKUB 


\section{PENDAHULUAN}

Secara mutlak agama dapat dijadikan sebagai identitas pembeda seseorang dengan orang lain (Christian 2017). Muchtar (2016), mengemukakan bahwa agama memegang peranan penting dalam kehidupan masyarakat dalam keadaan suci sesuai dengan kepercayaan. Agama sebagai lembaga pengawasan social berperan penting bagi pembangunan masyarakat. Umumnya berupa signifikan ganda, yaitu "potensial" sebagai "fungsional". Agama dapat dijadikan sebagai potensial yang mengandung ajaran moral dalam kehidupan bermasyarakat. Sedangkan dari segifungsional agama menjamin tatanan sosial. Sistem kepercayaan memiliki aturan baku yang dapat menjunjung tinggi ketaatan kepada Tuhan serta moralitas sehingga, agama mampu menjadi institusi kebenaran (the body of truth), hukum (law), ritual (rites) dan dopma transendental (Rosyid, 2015). Sebagai pluralitas agama hubungan umat beragama harus dilakukan dengan menjalankan konstitusional dan dijadikan sebagai paradigma kepercayaan menerima perbedaan dalam membangun persatuan dan kesatuan bangsa yang harmonis (Mubit, 2016).

Fungsi agama dapat membangun kehidupan masyarakat yang bermoral. Hal ini sesuai dengan (Faiz, 2018), membatasi aspek kepercayaan dan hukum merupakan pengertian dari agama. Agama dapat membawa perubahan yang positif untuk meningkatkan kemajuan konstruktif bagi pembangunan masyarakat,. Demi suksesnya pelaksanaan pembangunan nasional di Indonesia, kerukunan, toleransi dan harmoni antar umat beragama sehingga tercipta stabilitas nasional yang dinamis (Noupal, 2017). Dalam berbagai aspek agama dijadikan sebagai pilar utama bagi pembangunan masyarakat, hal ini dapat diwujudkan apabila masyarakat tetap menjunjung tinggi "keluhuran" dan "kearifan" serta mampu mengembang nilai moral agama (Atabik, 2015). Agama dapat memperkecil jurang sekularisme yang akan mengindikasi ketidakharmonisan kehidupan masyarakat dalam beragama dan bernegara. Pluralitas tercipta dari kerukunan hidup umat beragama melalui keterlibatan peran serta potensi yang disintegrasi maupun potensi integrasi. (Firdaus, 2014). Dalam menjalankan ajaran agama yang diyakini, keberagamanan dapat diartikan sebagai kesadaran diri setiap individu sebagai perilaku sikap seseorang dalam melaksanakan kewajiban agamanya. Dengan adanya konsistensi kepercayaan terhadap agama sebagai kognitif secara aktual, perasaan dan sikap perilaku terhadap agama secara efektif (Batoebara, 2018).

Setiap penduduk diberikan hak untuk memeluk agama dan kepercayaan masing masing. Karena setiap warga negara memiliki hak untuk berpikir secara bebas dalam 
keadaan apapun. Setiap orang bebas memilih dan menjalankan ajaran agama, dan menjunjung tinggi sikap saling menghargai terhadap kebebasan orang lain. Berdasarkan UUD 1945 Pasal 29 Ayat 2, pemerintah mempunyai tugas dan kewajiban melindungi setiap penduduk untuk memberikan bimbingan dan pelajaran sehingga dapat melaksanakan ajaran agamanya dengan rukun, aman, dan tertib. Hal ini sebagai bagian dari upaya pemerintah dalam menjaga toleransi yang beragam.

Keberagaman tidak dapat di hindari dalam kehidupan bermasyarakat. Sebagai contoh Indonesia memiliki multikultural yang berkaitan dengan etnis, suku, agama ras dan kepercayaan atau Bhineka Tunggal Ika. (Lestari, 2015). Hal tersebut menandakan berbagai kemajemukan yang bersifat horizontal maupun vertikal. Perbedaan horizontal meliputi kesatuan sosial contohnya suku bangsa, bahasa, adat istiadat dan agama. Sedangkan perbedaan vertikal yaitu perbedaan lapisan atas dan bawah contohnya dibidang sosial, politik dan budaya (Yudianita, 2015). Sebagai kaum pluralis, perbedaan akan menjadikan suatu pandangan hidup dan cita-cita sebagai dasar pijakan dalam kehidupan bersama (Firdaus, 2014). Dan inilah yang terjadi di Kabupaten Sikka. Masyarakat di Kabupaten Sikka memiliki agama yang berbeda-beda, ditandai dengan berbagai kegiatan keagamaan yang dilaksanakan sejak dulu oleh lintas agama yang menganutnya. Ini didukung kondisi masyarakat yang notabene saling menghargai setiap perbedaan dan keyakinan tiap individu serta tidak mengganggu kegiatan ibadah dari masing-masing agama.

Keberagaman tersebut tidak luput sering terjadi konflik yang diakibatkan oleh perbedaan ideologi kelompok yang menimbulkan sikap intoleransi dan diskriminasi. Peristiwa intoleransi pernah terjadi termasuk di Kabupaten Sikka pada tahun 1995. Untuk mengantisipasi hal tersebut, maka harus ada regulasi dan program kegiatan untuk memelihara ketenteraman dan ketertiban masyarakat, sebagai wadah yang menjembatani setiap perbedaan. (Ruhana, 2015). Sehingga dibentuklah Forum Kerukunan Umat Beragama (FKUB) sebagai tempat musyawarah serta solusi dalam penyelesaian konflik berdasarkan peraturan perundang-undangan yang berlaku. Dari permasalahan diatas jelaslah bahwa di Kabupaten Sikka masih ada masalah yang berkaitan dengan toleransi. Sehingga penulis ingin lebih jauh meneliti secara lebih dalam persoalan tersebut.

\section{METODE PENELITIAN}

Metode deskriptif kualitatif digunakan pada permasalahan yang sudah ditentukan sebelumnya agar lebih terarah. Gumilang (2016), mengatakan penelitian kualitatif 
digunakan agar mengetahui dan memahami teori yang tersembunyi dari suatu interaksi sosial sehingga dapat memastikan kevalidan data. Penelitian deskriptif kualitatif biasanya difokuskan untuk merumuskan pertanyaan penelitian dengan tujuan ketercapaian pengumpulan data secara langsung. Sumber data dalam penelitian ini adalah menggunakan data primer yaitu data yang diperoleh secara langsung dari informan. Sedangkan data sekunder merupakan data tidak langsung atau diberikan kepada pengumpul data contohnya buku literatur dan lain-lain. Penelitian ini menggunakan teknik pengamatan, wawancara, dan studi dokumentasi. Teknik analisis data yaitu reduksi data, model data, (Triangulasi), Penarikan dan verifikasi kesimpulan.

\section{HASIL DAN PEMBAHASAN}

\section{Peran Forum Kerukunan Umat Beragama (FKUB) Dalam Menjaga Toleransi Antar Umat Beragama di Kabupaten Sikka}

Organisasi ini dibentuk pada tanggal 21 Maret 2006 oleh masyarakat dan difasilitasi pemerintah daerah dalam waktu yang tidak ditentukan, organisasi ini memiliki kedudukan diseluruh wilayah Republik Indonesia meliputi Provinsi, Kabupaten/ kota. Dan ditingkat kecamatan apabila dianggap perlu.

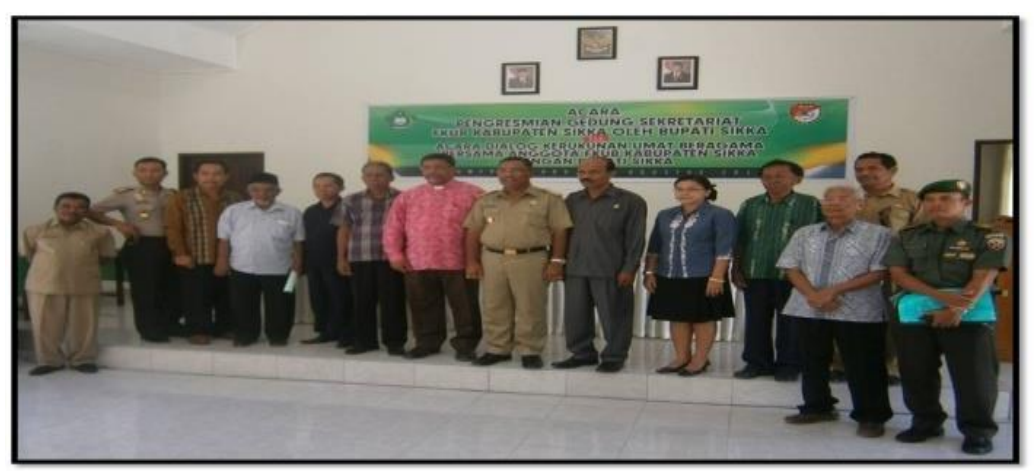

Gambar 1. Bupati Sikka Resmikan Gedung FKUB Kabupaten Sikka (Arsip Admin Kemenag NTT)

Forum Kerukunan Umat Beragama berasaskan Pancasila dan Undang-undang Dasar Republik Indonesia Tahun 1945 yang bersifat independen, dan memiliki hubungan yang bersifat konsultatif dan koordinatif antara Provinsi dengan FKUB Kab/Kota. Tujuan dibentuknya organisasi ini untuk memelihara serta menjaga kerukunan umat beragama dalam kehidupan bermasyarakat, berbangsa dan bernegara. Dari hasil penelitian yang dapatkan di lapangan bahwa Peran Forum Kerukunan Umat Beragama (FKUB) Kabupaten Sikka yaitu: 


\section{Sebagai Mediator Dan Motivator}

Untuk memediasi kerukunan umat beragama dalam penyelesaian konflik terjadi ditengah masyarakat. Mediasi merupakan cara yang dilakukan membuat konsensus kepada kedua pihak yang berselisi dan mencari pihak ke tiga sebagai mediator dengan memiliki kedudukan bersifat netral. Forum Kerukunan Umat Beragama (FKUB) berperan sebagai motifator dengan memberi motivasi khusus kepada pihak yang berselisih, serta memberikan arahan bagi masyarakat saling menjunjung tinggi, dan membedakan hal perlu dilakukan bersama atau sendiri dari agama masing- masing. Dari penjelasan tersebut terdapat persamaan dalam penelitian Rifa Atul Murtofi'ah (2015), FKUB berperan sebagai mediator dan motivator sedangkan perbedaan dari penelitian Rifa Atul Murtofi'ah dengan judul Peran Forum Kerukunan Umat Beragama (FKUB) Dalam Mengelola Kerukunan Antar Umat Beragama (Studi Kasus Di Desa Getas Kecamatan Kaloran Kabupaten Temanggung Tahun 2013- 2015). Dari sini dapat disimpulkan bahwa FKUB memberikan kontribusi untuk menjaga kerukunan umat beragama, pada level akar rumput masyarakat tetap hidup harmonis.

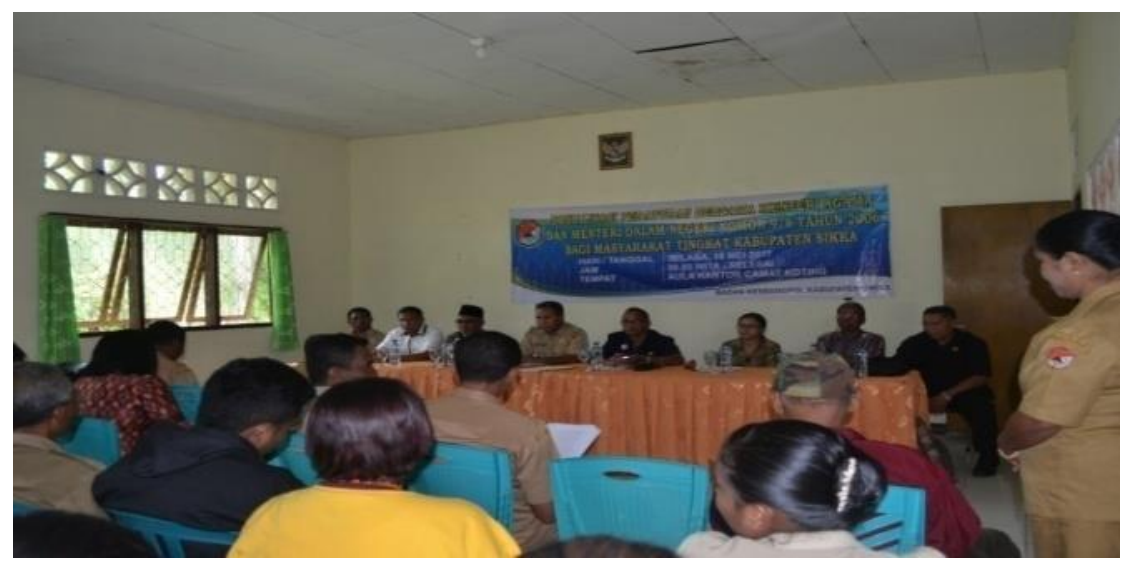

Gambar 2. Beri Materi Kerukunan Beragama, (Berita Boby Babaputra)

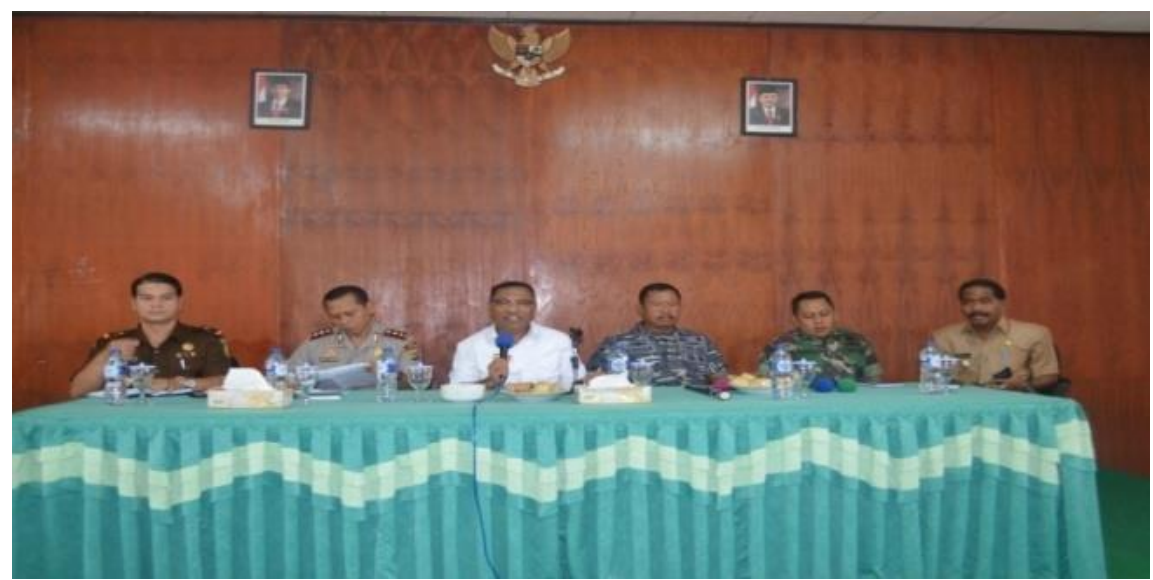

Gambar 3. Forkopimda, Kemenag Sikka, dan FKUB Bahas KUB, (erita Gerald Wassa) 
2. Melakukan Sosialisasi Nilai-Nilai Dalam Masing-Masing Agama

FKUB melakukan sosialisasi peraturan perundang-undangan di Kabupaten Sikka dengan cara kegiatan seminar dihadiri oleh tokoh agama dan masyarakat. Selain itu FKUB melakukan program dengan turun kekecamatan untuk melakukan sosialisasi tentang nilainilai sakral yang dianut oleh semua agama dengan maksud yang dianut warga di Kabupaten Sikka. Sehingga ada wadah yang dapat mempersatukan pemimpin-pemimpin umat beragama untuk merawat kerukunan antar umat beragama. Dengan demikian berdasarkan peraturan pemerintah forum kerukunan umat beragama berperan besar dalam mengimplementasikan kebijakan agar terciptanya masyarakat yang harmonis.

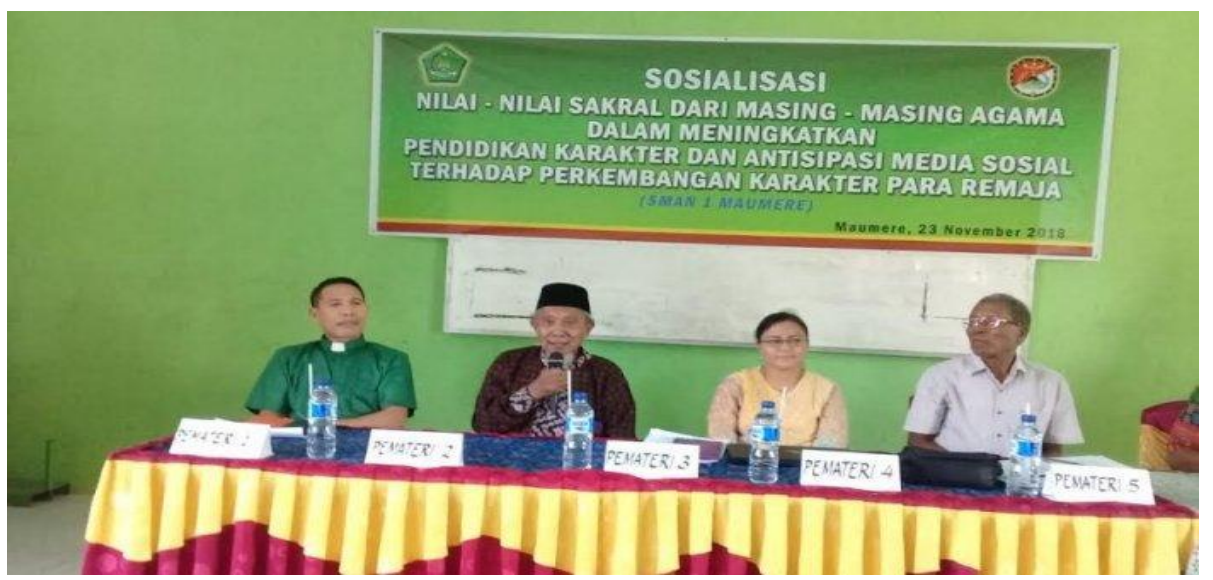

Gambar 4. Sosialisasi nilai-nilai sakral agama kepada siswa/i di Aula SMAN 1 Maumere,

Pulau Flores, Propinsi NTT, (Laporan Reporter Pos Kupang.Com, Euginius Mo’a)

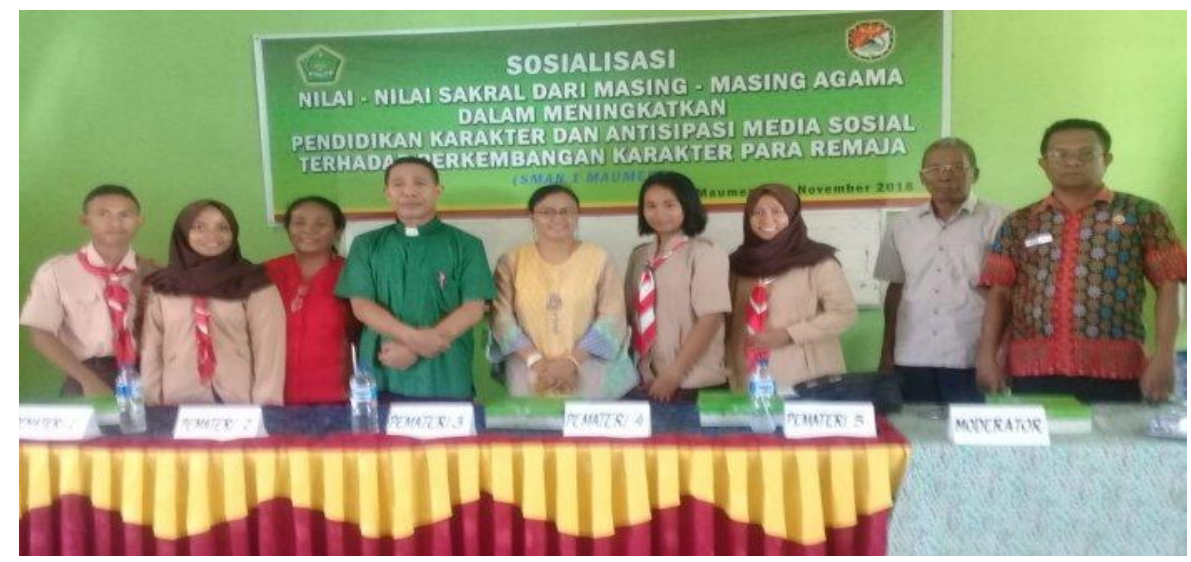

Gambar 5. Sosialisasi nilai-nilai sakral agama kepada siswa/i di Aula SMAN 1 Maumere, Pulau Flores, (Laporan Reporter Pos Kupang.Com, Euginius Mo’a)

3. Melakukan Dialog Dengan Pemuka Agama Dan Tokoh Masyaraka

Dialog dilakukan oleh FUKB bersama tokoh agama dan masyarakat membahas situasi dan kondisi kerukunan di Kabupaten Sikka secara terus menerus, dengan tujuan menyatukan tugas dan fungsi yang dilaksanakan. Hal ini disampaikan Siti Faridah (2018), 
Dialog antar umat beragama mampu mengantarkan kepada pemeluk pada corak kehidupan yang inklusif dan terbuka yang berpotensi menimbulkan jiwa toleransi antar masyarakat. Dialog didasari dengan pemikiran yang pluralitas sehingga diharapkan membawa umat beragama pada konsep "unity in diversity" dan "to life together".

Selain itu FKUB Kabupaten Sikka bukan hanya suatu organisasi yang sif tetapi format komunikasi yang di bangun dapat memberikan pemahaman terhadap agama dan masing-masing tokoh politik, sehingga masyarakat tertarik pentingnya FKUB. Apabila tanpa adanya FKUB maka menimbulkan persoalan dan isu-isu yang dapat merusak kerukunan umat beragama sehingga dapat mengambil keputusan sendiri. Dengan hadirnya FKUB sekaligus menjadi daya perekat bagi agama-agama yang ada di Kabupaten Sikka saling berbagi dan mencari solusi dari masing-masing agama sehingga masyarakat merasa puas dan dapat merespon cepat terhadap hal-hal yang mengganggu kerukunan,

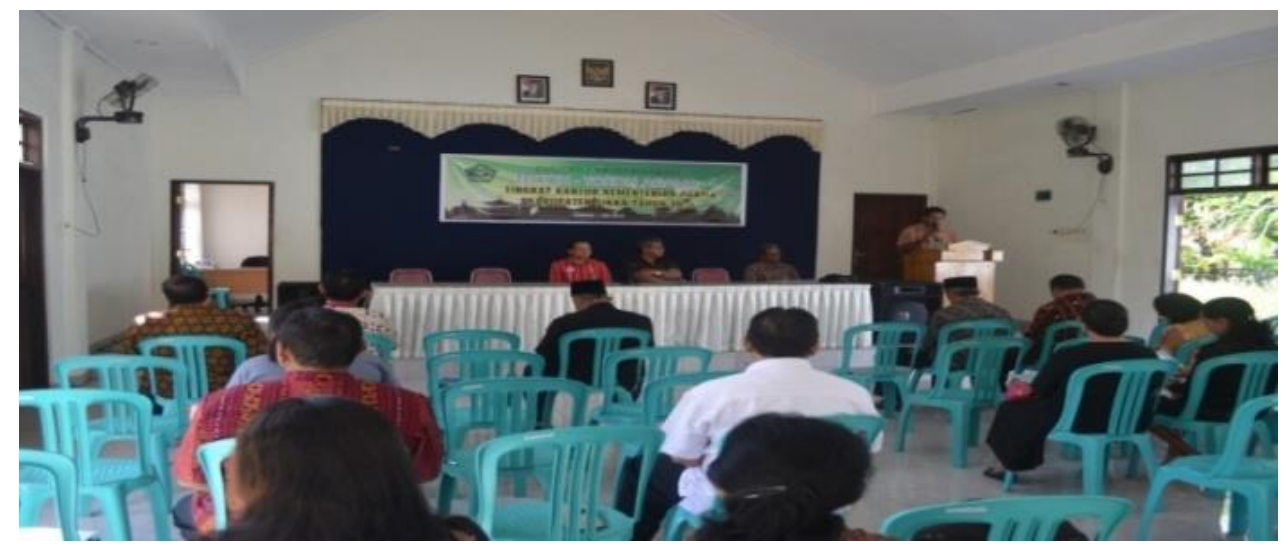

Gambar 6. Tokoh Agama Sikka gelar Dialog Bersama, (Berita Boby Babaputra)

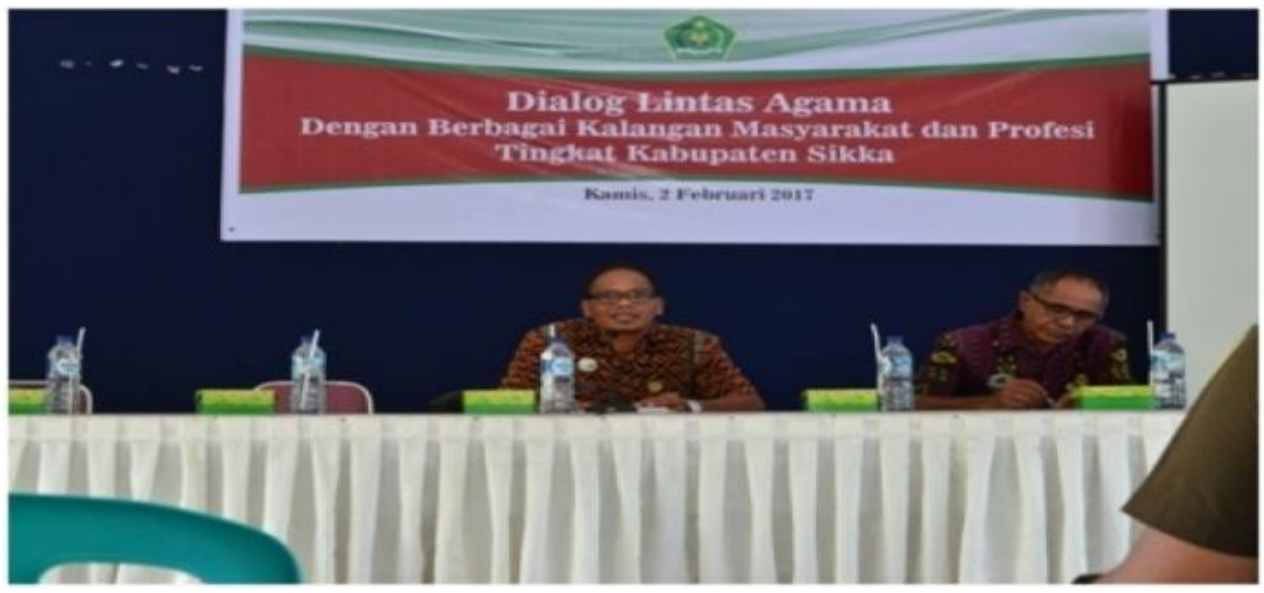

Gambar 7. Hak Beragama Merupakan Salah Satu Hak Asasi Manusia (sourcentt.kemenag.go.id repost: dita - pkub) 
4. Menampung dan menyalurkan aspirasi ormas keagamaan dan aspirasi masyarakat

FKUB berperan penting dalam menampung dan menyalurkan aspirasi masyarakat sebagai jembatan untuk musawarah mufakat. Setiap 3 bulan FKUB melakukan pertemuan membahas serta memberikan solusi terhadap masalah intoleran. FKUB tidak memaksakan suatu umat untuk memeluk agama lain, akan tetapi FKUB memberi kebebasan umat yang ada di Kabupaten Sikka untuk memilih agama yang dipercaya atau diyakini, dan tetap menghargai eksistensi agama lain, sepanjang tidak mengusik akidah atau kepercayaan lain, dan tetap memberikan kebebasan untuk menjalani agama masing- masing.

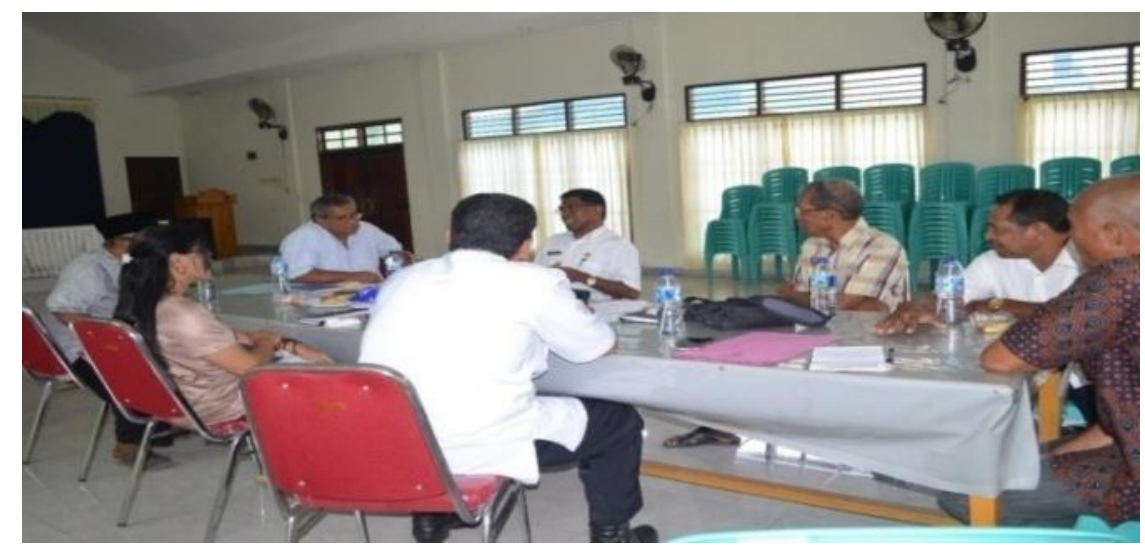

Gambar 8. Diskusikan Rehab Masjid Al-Muhajirin, FKUB Sikka Bahas Rekomendasi dan IMB, (Berita Boby Babaputra)

FKUB melakukan perannya dengan menggunakan pendekatan kearifan lokal. Dimana kebudayaan orang maumere seperti prinsip "masuk kandang kambing ngembik masuk kandang ayam berkotek" adalah prinsip mengikat setiap kehidupan masyarakat Kabupaten Sikka. Selain itu budaya lokal yang ada dimasyarakat Sikka menggunakan prinsip “ Uhe Die Dang Hading” yang berarti “pintu terbuka tangga terpasang”, memiliki makna keterbukaan dalam menerima semua serta tidak mengenal, suku, ras, dan agama. Menurut Dewa Agung (2017), kebudayaan merupakan acuan bersama sebagai perangkat nilai, norma dan tradisi yang dijalankan oleh kelompok sosial yang berhubungan dengan Tuhan, alam dan sesama manusia. Kehidupan keagamaan masyarakat Kabupaten Sikka cukup kondusif. Hadirnya agama di Kabupaten Sikka secara historis antara lain masuknya Islam melalui orang Gowa-Sulawesi Selatan, kemudian Khatolik dibawa orang Portugis, Kristen dibawa oleh orang Belanda, serta Hindu dan Buddha masuk melalui orang Bali, yang bertugas di Kabupaten ini. FKUB dan pemerintah dalam hal ini Kementerian Agama memiliki peran yang strategis serta tidak dapat dilepaskan dalam menjaga toleransi umat beragama di Kabupaten Sikka, seperti yang dijelaskan Dr. Achmad Jamil mengatakan bahwa dalam menjalankan tugasnya Kementrian Agama bertindak sebagai polisi lalu 
lintas, yang memiliki tugas sebagai pengawas dan pengontrol serta menjamin kepada seluruh umat beragama untuk menjalankan kepercayaan dan keyakinannya (Jamil, 2015).

Selain itu pemerintah daerah ikut berperan dalam menjaga toleransi, dalam hal ini badan kesatuan bangsa dan politik serta para penegak hukum dalam mewujudkan kesatuan dan persatuan bangsa. Peran dari badan kesatuan bangsa dan politik memberikan perlindungan kepada masyarakat, selain itu para penegak hukum harus menjadi eksekutor dalam memelihara kerukunan masyarakat.

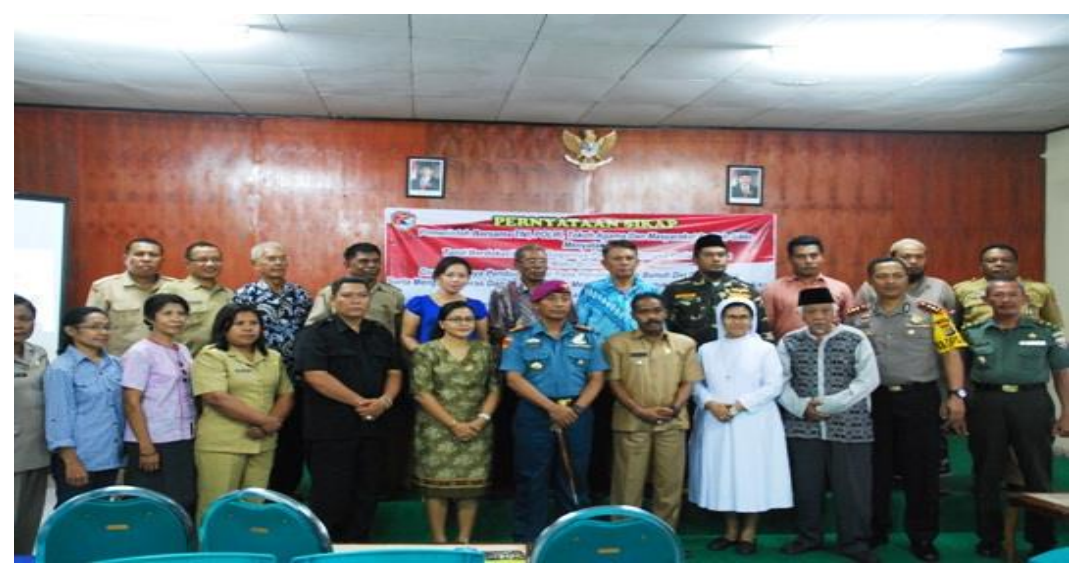

Gambar 9. FKUB Sikka Tegas Tolak Aksi Teroris di Tanah Air (By Redaksi Posted on Mei 17, 2018)

Masyarakat di Kabupaten Sikka merupakan masyarakat multikultural yang memiliki berbagai perberbedaan namun masyarakat selalu hidup berdampingan, dan kerjasama sosial dalam menjaga kerukunan.

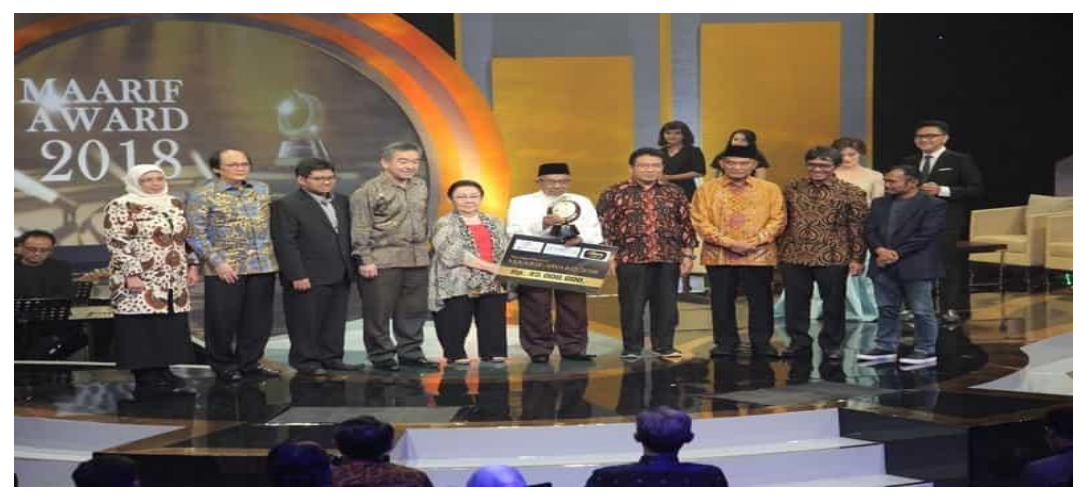

Gambar 10. Abdul Rosyid Wahab, Penganjur Toleransi Dari Sikka Terima MAARIF Award 2018 (Headline Nasional 28/05/2018 alex)

Salah satu contoh yaitu propinsi NTT mendapatkan peringkat ke 4 yaitu sadar kerukunan yang tertinggi di Indonesia yang diakui secara Nasional bahkan secara Internasional. Hal ini dibuktikan disalah satu kelurahan yaitu kelurahan kota uneng kecamatan alok sebagai contoh kelurahan sadar kerukunan umat beragama berdasarkan surat keputusan pemerintah kabupaten sikka nomor 09/FKUB.kab Sikka/VII/2019 tanggal 26 Juli 
2019 tentang pencanangan kelurahan sadar kerukunan dan rekomendasi FKUB, Kemenag dan Kesbangpol Sikka.

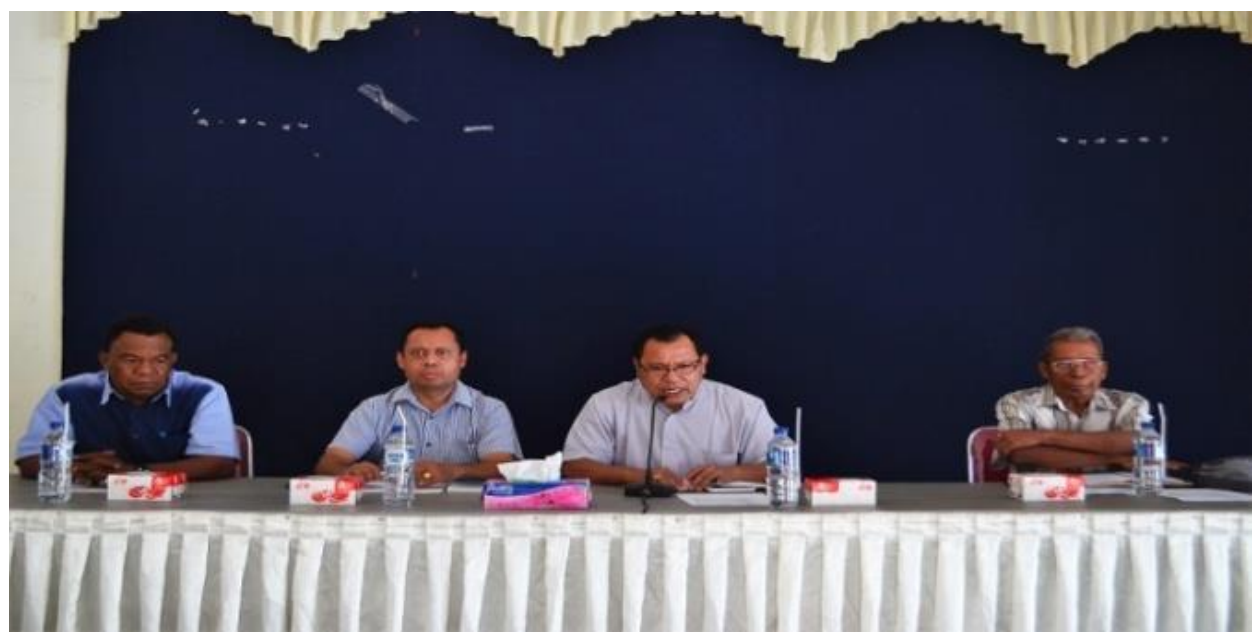

Gambar 11. FKUB Sikka Bentuk Panitia Kegiatan Launching Kota Uneng Jadi Kelurahan Percontohan Sadar Kerukunan Umat Beragama,, (BeritaYanto Ngadji)

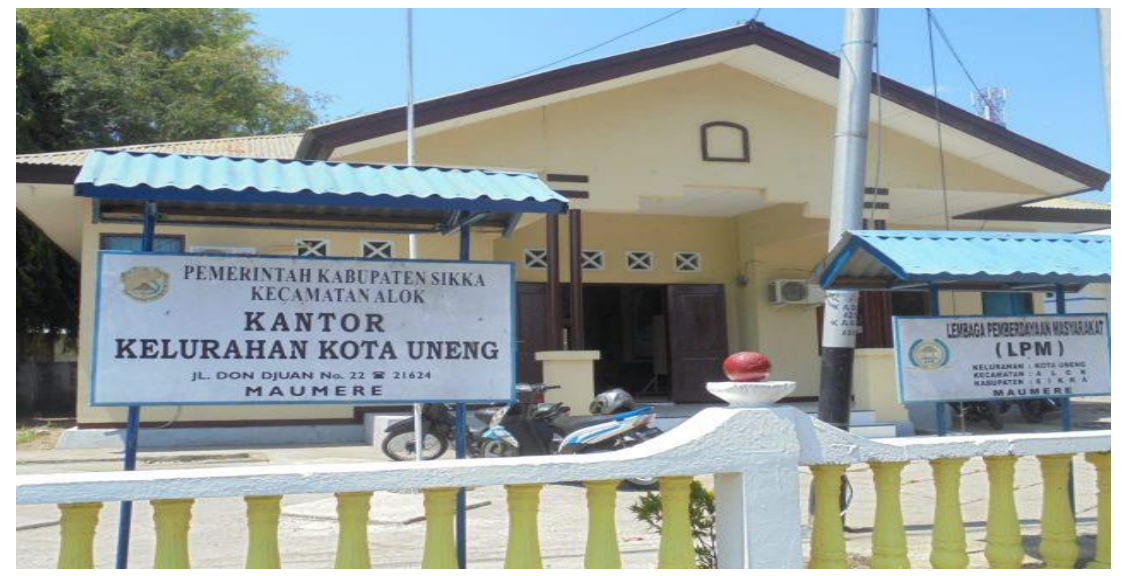

Gambar 12. Kantor Kelurahan Kota, (Redaksi Ekorantt.com)

Kehidupan masyarakat akan baik jika terjaga kerukunan umat beragama yang harmonis. Salah satu contoh adanya lembaga pendidikan formal diantaranya IKIP Muhammadiyah Maumere, SMA Muhammdiyah Maumere dan SMP Muhammadiyah Waipare. Adanya lembaga pendidikan ini sangat memperkuat adanya toleransi beragama karena lembaga pendidikan ini dalam prakteknya menerima mahasiswa dari semua kalangan dan agama, tidak memandang suku, ras, budaya dan agama. 


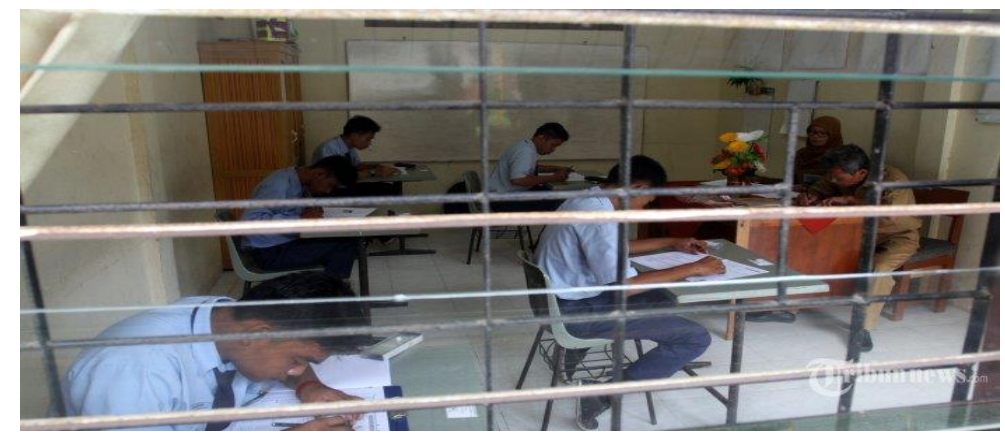

Gambar 13. Pelaksanaan UN Di SMP Muhammadiyah Waipare

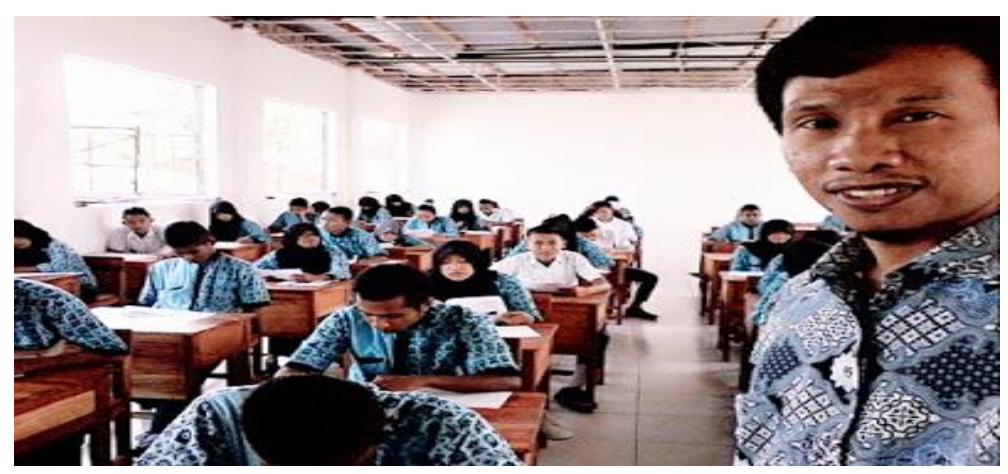

Gambar 14. Kegiatan Belajar Mengajar Di SMA Muhammadiyah Maumere

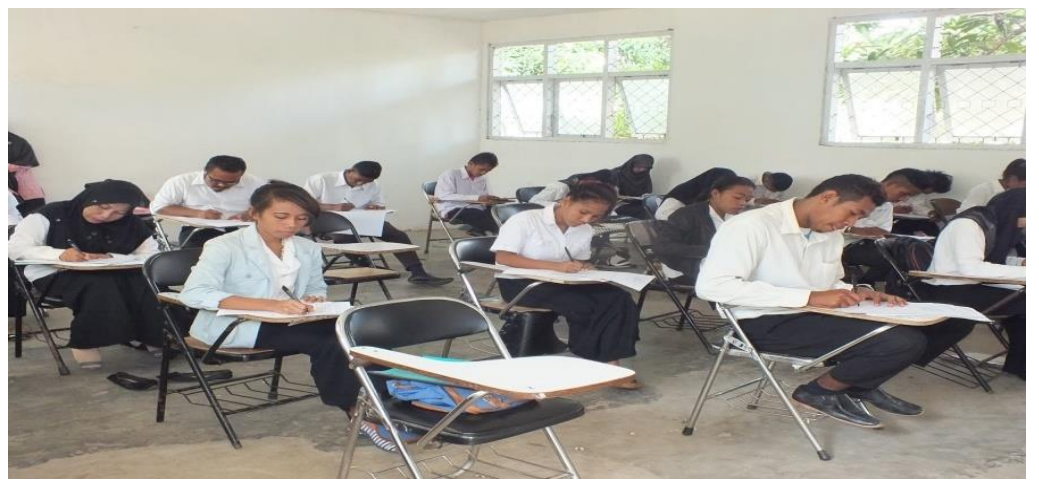

Gambar 15. Kegiatan Proses Perkuliahan Di Kampus IKIP Muhammadiyah Maumere

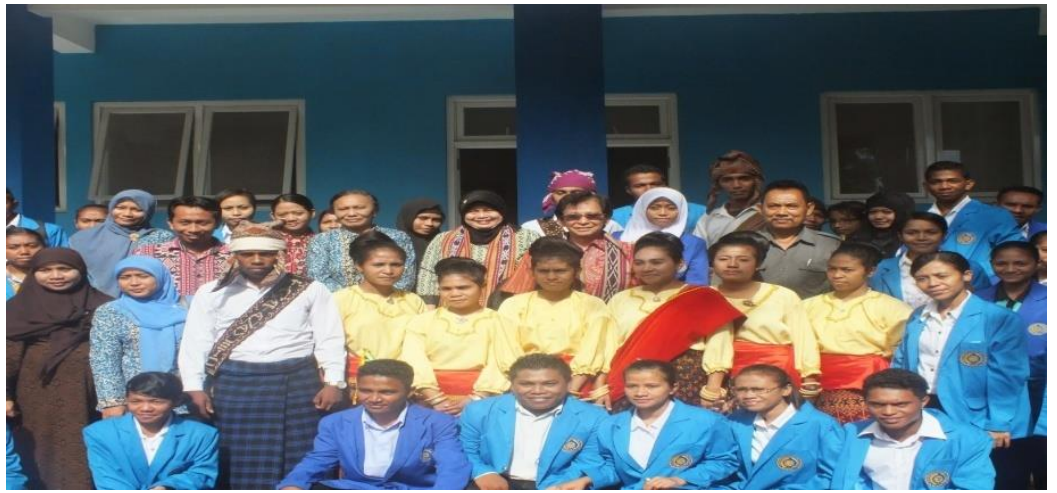

Gambar 16. Kegiatan Acara Bersama Dalam Kampus IKIP Muhammadiyah Maumere 
Kendala Yang Dihadapi Oleh Forum Kerukunan Umat Beragama (FKUB ) Kabupaten Sikka

1. Faktor Biaya

Setiap kegiatan FKUB disponsori dana dari Kemenag namun, biaya tersebut sangat terbatas sehingga pelaksanaan kegiatannya juga sesuai dengan dana yang ada (Mulyadi, 2009). Data tersebut menjadi poin penting untuk ditindak lanjuti karena persoalan intoleran dapat terjadi ketika kurangnya materi kepada masyarakat akan pentingnya kerukunan antar umat beragama.

2. Faktor Dukungan Pemerintah

Dalam melakukan kegiatan FKUB didukung oleh pemerintah, lembaga keagamaan, tokoh agama dan masyarakat sehingga dapat memberikan kontribusi terhadap setiap kebijakan dalam hal kerukunan dan kedamaian (Solichin, 2004).Oleh karena itu Pemerintah harus memberikan kontribusi dari setiap kebijakannya dalam menyelesaikan segala permasalahan yang ada di tengah masyarakat. Maka dapat disimpulan bahwa kebijakan dapat mencerminkan sebuah tanggapan dan tatanan secara administrasi dan sistem politik terhadap realita sosial yang dianggap harus ditindaklanjuti.

\section{SIMPULAN}

Peran FKUB di Kabupaten Sikka sudah dilaksanakan dengan baik yaitu sebagai mediator dan motivator, melakukan sosialisasi, nilai-nilai masing-masing agama, melakukan dialog dengan pemuka agama dan tokoh masyarakat, menampung dan menyalurkan aspirasi ormas keagamaan dan aspirasi masyarakat. Namun masih terkendala pada anggaran operasional. Masyarakat Kabupaten Sikka merupakan masyarakat multikultural yang memiliki berbagai etnis suku, budaya adat dan bahasa. Oleh karenanya dalam menjaga toleransi tersebut, FKUB terus mengupayakan dengan melibatkan tokoh agama dan masyarakat yang kreatif dan inovatif agar dapat menciptakan kondisi kehidupan masyarakat yang tertib, rukun dan damai.

\section{DAFTAR PUSTAKA}

Abd Aziz Faiz 2018, Kebijakan Negara dalam Mengakomodir Agama Pribumi Perspektif Sosial-Antropologi, Universitas Islam Negeri (UIN) Sunan Kalijaga Yogyakarta, Jurnal Pemberdayaan Masyarakat: Media Pemikiran dan Dakwah Pembangunan Vol. 2, no. 2 (2018), hal. 221-238.

Abdul Wahab, Solichin. 2004. Analisis Kebijaksanaan dari Formulasi ke Implementasi Kebijaksanaan Negara. Jakarta: Bumi Aksara. 
Ahmad Atabik 2015, Konsep Penciptaan Alam, Studi Komparatif-Normatif antar AgamaAgama, Jurnal Ilmu Aqidah dan Studi Keagamaan Volume 3, No.1, Juni 2015 halaman 101-219.

Akmal Salim Ruhana 2015. Peran Pemerintah Daerah Dalam Pemeliharaan Kerukunan Beragama Di Provinsi Kepulauan Riau.Jurnal Bina Praja, Volume 7, Nomor 2, halaman $185-194$.

Dewa Agung Gede Agung 2017 Keragaman Keberagamaan (Sebuah Kodrati Kehidupan Berbangsa Dan Bernegara Berdasarkan Pancasila), Sejarah Dan Budaya, Tahun Kesebelas, Nomor 2, Desember 2017 halaman 151-159.

Dr. Acmad Jamil, "Modul Perkuliahan Kewarganegaraan, (Universitas Mercu Buana, 2015).

Faridah, Siti (2018). "Kebebasan Beragama Dan Ranah Toleransinya”, Lex Scientia Law Review. Volume 2 No. 2, November, hlm. 199 -214.

Feby Yudianita 2015 Tinjauan Yuridis Terhadap Aliran Kepercayaan Dihubungkan Dengan Pasal 29 Ayat 2 Uud 1945 JOM Fakultas Hukum Volume 2 Nomor 2 Oktober 2015 halaman 1-14.

Gina Lestari 2015, Bhinnekha Tunggal Ika: Khasanah Multikultural Indonesia Di Tengah Kehidupan Sara, Pendidikan Pancasila dan Kewarganegaraan, Th. 28, Nomor 1, Pebruari 2015 halaman 31-37.

Ibnu Hasan Muchtar 2016 Eksistensi dan Peran Rohaniwan Asing Terhadap Perkembangan Kehidupan Keagamaan di Kabupaten Sikka, NTT, Jurnal Multikultural \& Multireligius Vol. 15 No. 2 halaman 68-79.

Maria Ulfa Batoebara 2018, Membangun Trust (Kepercayaan) Pasangan Dengan Melalui Komunikasi Interpersonal. Jurnal Warta Edisi : 57 Juli 2018 | ISSN : 1829-7463.

Moh. Rosyid 2015. Mewujudkan Pendidikan Toleransi Antar-Umat Beragama Di Kudus: Belajar Dari Konflik Tolikara Papua 1 Syawal 1436 H / 2015 M. Jurnal Pendidikan Islam, QUALITY, Vol. 3, No. 2, halaman 370- 409.

Muh. Anang Firdaus. 2014. Melacak Peran Forum Kerukunan Umat Beragama (FKUB) Di Jayapura. Sekolah Tinggi Agama Islam Negeri (STAIN) al-Fatah di Jayapura. Jurnal Diskursus Islam, Volume 2 Nomor 1, halaman 1- 34.

Muhammad Anang Firdaus 2014. Eksistensi Forum Kerukunan Umat Beragama dalam Memelihara Kerukunan Umat Beragama di Indonesia Kontekstualita, Vol. 29, No. 1, halaman 58- 71.

Muhammad Noupal 2017, Paradigma Integralistik dan Toleransi Umat Beragama di Kota Palembang, Intizar, Volume 23, Nomor 1, 2017 halaman 73-92.

Mulyadi. 2009. Akuntansi Biaya, Edisi 5. Yogyakarta: UPP STIM YKPN. 
Rifa Atul Murtofi'ah. (NIM 111311045). SKRIPSI judul Peran Forum Kerukunan Umat Beragama (FKUB) Dalam Mengelola Kerukunan Antar Umat Beragama (Studi Kasus di Desa Getas Kecamatan Kaloran Kabupaten Temanggung tahun 20132015).

Rizal Mubit 2016, Peran Agama Dalam Multikulturalisme Masyarakat Indonesia, Pascasarjana IAIN Tulungagung, Epistemé, Vol. 11, No. 1, Juni 2016 halaman 163184.

Symphony Akelba Christian 2017 Identitas Budaya Orang Tionghoa Indonesia Jurnal Cakrawala Mandarin Asosiasi Vol.1, No.1, April 2017, halaman 11-22.

Galang Surya Gumilang, 2016, Metode Penelitian Kualitatif Dalam Bidang Bimbingan Dan Konseling, Jurnal Fokus Konseling Volume 2 No. 2, Agustus 2016 Hlm. 144159. 